\title{
Mowing may bring about vegetation change, but its effect is strongly modified by hydrological factors
}

\author{
Aleksander Kołos $(\mathbb{D} \cdot$ Piotr Banaszuk
}

Received: 26 March 2018/Accepted: 25 June 2018/Published online: 3 July 2018

(C) The Author(s) 2018

\begin{abstract}
We assessed the effect of long-term (11 years) mowing with a hand scythe on the distributions of plant species and species turnover within meadow communities dominated by Carex acutiformis and C. acuta in a small lowland river valley subjected to annual flooding. We hypothesized that mowing would trigger the process of species exchange toward multispecies communities according to the abiotic environmental gradients, as has been reported for traditionally used wet meadows. We found that mowing had a much greater impact on the increase in plant species abundance in wetter, subjected to deeper and longer flooding, zone of the valley than in its drier part. The treatment and hydrology had no substantial effect on the sedges and cryptogams while the graminoids and the forbs were the least stable components of the plant communities. We found that annual management was conducive to the appearance of numerous seedlings of Alnus glutinosa in the part of wetland situated close to the valley edge. Surface flooding was found to be a driving force modifying the impact of mowing on sedge meadows. This "hydrological resetting impulse" created a specific floristic
\end{abstract}

\footnotetext{
A. Kołos $(\bowtie) \cdot$ P. Banaszuk

Department of Agri-Food Engineering and Environmental Management, Białystok University of Technology,

Wiejska 45A, 15-351 Białystok, Poland

e-mail: a.kolos@pb.edu.pl

P. Banaszuk

e-mail: p.banaszuk@pb.edu.pl
}

reset of the community, bringing it to the more simplified forms. Mowing every $4-5$ years at the beginning of August is advisable to protect sedge meadows distributed in flooded small lowland river valleys.

Keywords Mowing - Carex meadows - Wetland · River flooding

\section{Introduction}

Valley wetlands and wet meadows are essential elements of the agricultural landscape in Europe, where for hundreds of years they have been continuously managed as a source of fodder. Semi-natural open ecosystems, dominated by sedges or grasses, developed due to the deforestation of the floodplains. Thus, their strong feature is the relatively high level of groundwater and the variably intense surface floods that occur most years (Marcinkowski and Grygoruk 2017). Extensive farming and the regular removal of biomass at a low or intermediate level of disturbance (Berglund et al. 2008) have contributed to the development of tree-less ecosystems with specific combinations of biota (Horak and Safarova 2015; Żmihorski et al. 2015), often rare, and protected by law (Natlandsmyr and Hjelle 2016). 
However, the existence of these ecosystems is now threatened by extensive drainage and river regulation works as well as an abandonment of traditional farming practices (Tälle et al. 2015). Cessation of the agricultural use of wetlands is particularly common in central Europe and the Baltic States but also occurs in North America (Joyce 2014). Therefore, in recent years, considerable emphasis has been put on active conservation combined with the restoration of the hydrology of degraded riverine wetlands. It is advisable to implement vegetation management such as removal of trees and shrubs, grazing, and mowing (van Diggelen et al. 2006; Grygoruk et al. 2014). Mowing is one of the most common treatment prescriptions (Middleton et al. 2006). However, its effect on non-forest ecosystems was found to depend on several factors, among which the most important are the timing and frequency of treatment and the type of cutting equipment used (Banaszuk et al. 2016; Milberg et al. 2017). An expected positive result of cutting and removing of biomass is usually related to a reduction in litter cover and vegetation height and the formation of gaps that create space for weaker competitors entering sub-optimal habitats at the tolerance limit (Keddy 2010). Consequently, the removal of biomass usually supports significant quantitative and qualitative changes, including increases in floristic richness and floristic diversity, in plant communities (Menichino et al. 2016). Additionally, vegetation management explicitly prevents the encroachment of woody species and invasive alien species into open communities and prevents the extinction of rare and endangered plant species (Kołos and Banaszuk 2013; Seer and Schrautzer 2014). The effectiveness of the management, measured as a return to the desired combination of target species, has been found to be profoundly modified by the habitat (Sorrell et al. 2007). Environmental determinants could be of paramount importance in determining the species pool of meadow communities, and the richness of vascular plants within mown meadows can be explained by abiotic factors, primarily by hydrology (Leyer 2005; Kołos and Banaszuk 2013). In some regions this impact can be exacerbated by future climate change, which can affect the hydrology of wetlands and wet meadows in some unpredicted way (Thuiller et al. 2005).

In this study, we assessed the effects of vegetation management and hydrology on the distributions of plant species and species turnover within sedge meadow communities in a small lowland river valley subjected to regular flooding. We hypothesized that mowing abandoned Carex communities with a hand scythe would trigger the process of establishment of wet meadow species, especially forbs, that were previously hindered by clonally growing rush plants. We assumed that changes in floristic composition caused by mowing will be modified by abiotic conditions prevailing in various parts of the river valley, as has been reported for traditionally used wet meadows (e.g., Pałczyński 1984).

\section{Materials and methods}

Study site

Chwiszczej is a small river in the SW foreland of the Białowieża Forest (NE Poland; Fig. 1), with a length of $13 \mathrm{~km}$ and a catchment area of $35.5 \mathrm{~km}^{2}$. The mean annual precipitation in this part of the region is $613.3 \mathrm{~mm}$, with rainfall from April to September totaling $381.3 \mathrm{~mm}$ (Tyszka 2008). The upper course of the valley is narrow and covered by wet meadows and pastures (Niczyporuk and Wiater 2006). The lower $5 \mathrm{~km}$ stretch is ca. $1 \mathrm{~km}$ wide, paludified and occupied by sedge (Magnocaricion) and rush communities (Phragmition), with spots of megaforb communities (Filipendulion) and gray willow shrubs. Alder forests cover $8 \%$ of the valley (Tyszka 2008).

In the middle of the twentieth century, the valley was reclaimed, resulting in a considerable lowering of the groundwater and over-drying of the organic soils, especially in its central part. Despite these hydrological changes, the valley is flooded almost every year during the early spring high flow events, and usually the inundation lasts until the end of May. Depending on the year, the depth of the flood varies from a few to $>40 \mathrm{~cm}$, and it is always deeper in a backswamp in the valley edge zone than in the slightly elevated zone along the riverbed. At the end of the vegetation season (August-October), the groundwater level often drops to as much as $50-80 \mathrm{~cm}$ below ground level. The electrolytic conductivity of the groundwater ranges between 271 and $366 \mu \mathrm{S} \mathrm{cm}^{-1}$ in the near-stream zone and from 284 to $597 \mu \mathrm{S} \mathrm{cm}^{-1}$ at the edge of the valley. The groundwater is rather low in $\mathrm{N}_{-} \mathrm{NO}_{3}{ }^{-}$, with concentrations of $0.20 \pm 0.19 \mathrm{mg} \mathrm{L}^{-1}$ near the 

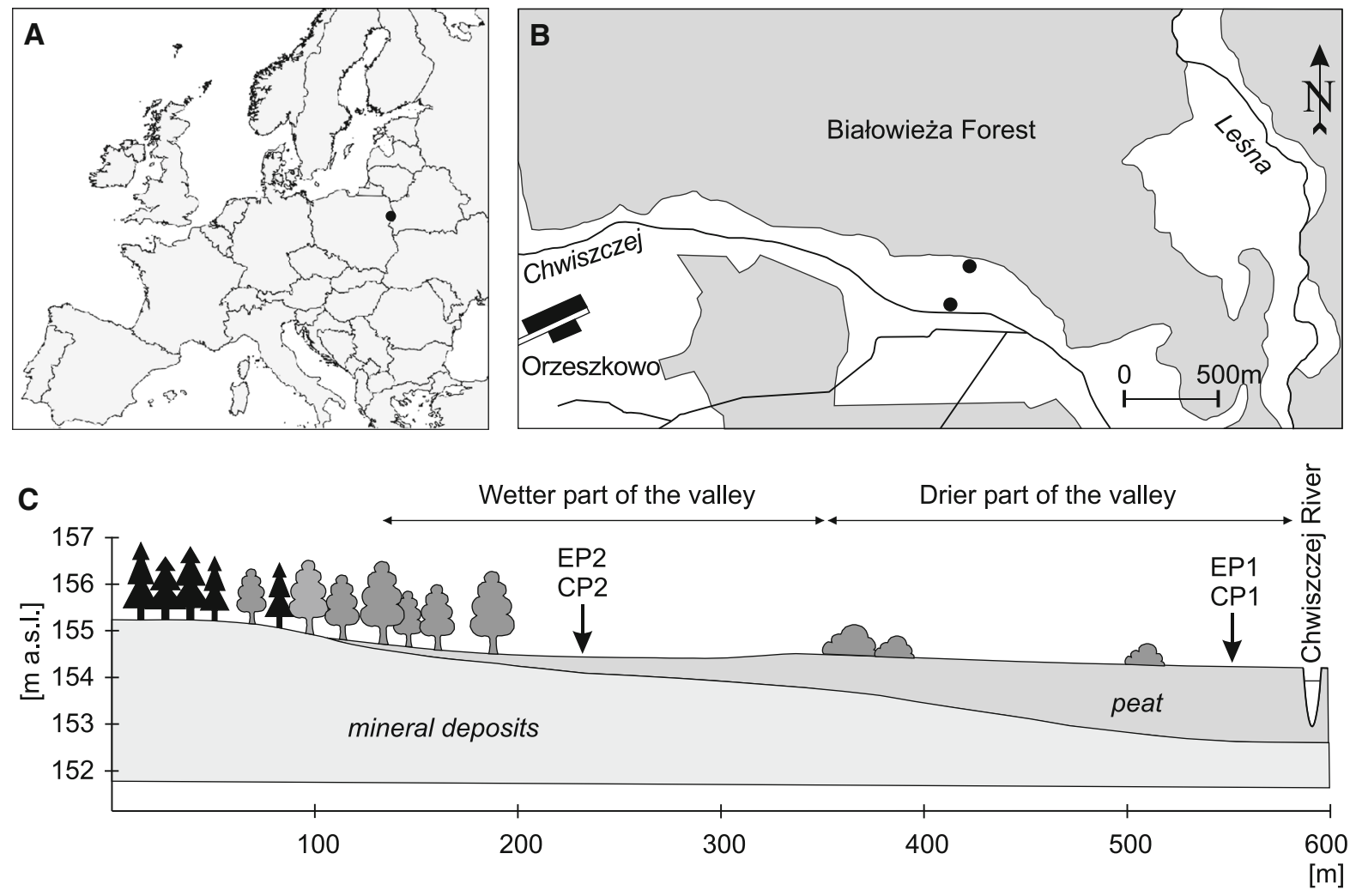

Fig. 1 Location of the study sites (A, B) and cross-section (C) trough the Chwiszczej river valley-a simplified extrapolation of peat profile analysis

stream and $0.06 \pm 0.07 \mathrm{mg} \mathrm{L}^{-1}$ at the valley margin, whereas the concentration of $\mathrm{N}-\mathrm{NH}_{4}{ }^{+}$is $0.69 \pm 0.44$ and $0.23 \pm 0.25 \mathrm{mg} \mathrm{L}^{-1}$, respectively, and $\mathrm{P}-\mathrm{PO}_{4}{ }^{3-}$ is $0.10 \pm 0.06$ and $0.06 \pm 0.07 \mathrm{mg} \mathrm{L}^{-1}$, respectively. The content of calcium is higher in areas fed by groundwater at the valley margin $\left(70 \pm 14.1 \mathrm{mg} \mathrm{L}^{-1}\right)$ than that in its central zone $\left(48 \pm 7.0 \mathrm{mg} \mathrm{L}^{-1}\right)$.

Sedge peat dominates in the valley, but near the riverbed, the upper layer up to $25 \mathrm{~cm}$ deep is mineralized (Kołos 2012). The thickness of histosols ranges between $0.5 \mathrm{~m}$ near the edge and $1.5 \mathrm{~m}$ near the stream.

Agricultural management of meadows ceased gradually starting during the middle of the twentieth century, and the last harvest was performed at the beginning of 1980. Currently, some part of the valley is mown within the framework of the protection of feeding grounds for birds of prey. Since 2003 a part of the valley is protected as the nature reserve Lasy Naturalne Puszczy Białowieskiej.
Vegetation study; mowing experiment

The extent of the experiment was limited to mitigate any adverse impact of the management practices on the nature reserve. Therefore, two experimental (mown) plots EP and two control plots $\mathrm{CP}$ were established in 2006. They were set within sedge meadows dominated by Carex acutiformis and $C$. acuta. One pair of experiment-control plots was placed near the riverbed (EP1, CP1), while the other was located in the backswamp near-edge zone of the valley (EP2, CP2). To minimize the impact of the surrounding vegetation, homogeneous plots with a relatively large area were established. Each plot was a square $\left(10 \times 10 \mathrm{~m}^{2}\right)$ and was divided into four subplots of $5 \times 5 \mathrm{~m}^{2}$ each. The experimental plots were mowed with a hand scythe every year at the beginning of July to mimic a traditional type of management. The biomass was removed directly after mowing. Plots were mowed with $2 \mathrm{~m}$ wide "buffer" to minimize the edge effect from the surrounding vegetation. The 
experiment started in 2006 and was conducted until 2016.

The changes in the floristic composition caused by mowing were documented by relevés in compliance with the Braun-Blanquet scale. Data were collected for every plot over an area of $25 \mathrm{~m}^{2}$ directly before mowing. Plant species occurring in the study areas were assigned to four functional groups: sedges, graminoids, forbs/megaforbs, and cryptogams (Barkman 1988).

The groundwater level was monitored once a month from May to November in two wells placed near the study plots.

\section{Data analysis}

Correspondence analysis (CA) was used to analyze changes in species composition caused by annual mowing of sedge meadows (Syntax 5.01 software; Podani 1993). Cover percentage approximations of the Braun-Blanquet cover-abundance scale were transformed according to van der Maarel (1979). The rate of species exchange in subsequent years in the period 2006-2016 were measured as the turnover index, T. This index was calculated as $\mathrm{T}=\mathrm{A}+\mathrm{D} / \mathrm{N}$, where $\mathrm{A}$ is the number of species that had appeared in the plot since the previous year (new species), D is the number of species that had disappeared from the plot in the given year (lost species), and $\mathrm{N}$ is the total number of species in the previous year in the plot (Berlin et al. 2000). Differences in the floristic richness between the treatments and controls were analyzed using a nonparametric Mann-Whitney U-test.

Weather data from the Bialystok weather station were obtained from IMiGW in Warsaw. The trends in temperature and precipitation were detected by fitting various types of regression models to the data, using time as the independent variable. The best statistically significant model that fitted the time series data was selected using Akaike Information Criterion (Statgraphics Centurion XVI software; Statgraphics Technologies, Inc. the Plains, Virginia, USA).

To detect possible fluctuations in climate records on interannual time scales, we applied parametric interpolation and prediction, which is a composite algorithm that generates a parametric (sinusoids or damped sinusoids) model of the signal. The algorithm is performed in three steps. In the first step, an AR, Prony, eigenanalysis, or Fourier procedure is used to estimate the frequencies and component count. In the second step, a linear fit is performed to learn the amplitudes and phases, which are the starting estimates for the non-linear optimization (the third step).

Wavelet transformation was used to identify the dominant cycle periods. We applied continuous wavelet transform (CWT) in a limited 2D spectral format. Analyses were performed with AutoSignal v. 1.7 (Systat Software, Inc. CA, USA).

\section{Results}

Climate and groundwater

NE Poland is facing considerable changes in climatic parameters, with a clear trend toward a milder climate. Statistically significant $(\mathrm{p}<0.05)$ upward trends have been observed for the average air temperatures of the winter and spring months, February-April, and summer months, July and August, although the observed pattern of variability was different for those two periods (Fig. 2A, B). Due to milder winters and warmer summers, over the last 60 years, annual average temperature increased from 6.8 to nearly $8{ }^{\circ} \mathrm{C}$ (Fig. 2C).

There was no clear trend in the annual rainfall. The annual precipitation oscillated around the mean decadal value of $590 \mathrm{~mm}$ and changed from $>850 \mathrm{~mm}$ in the extremely wet years, such as 1970 and 2010 , to $<450 \mathrm{~mm}$ recorded in dry years, such as 1951, 1953, 1971, 1982 and 2000. The same pattern was exhibited for the precipitation in the summer months.

In the most recent decade, milder winters contributed to a decrease in the depth of snow cover. However, although there was a high interannual variability and visible changes in snow extremes, we did not detect any tendency toward decreases in the depth of snow on the ground over the past 50 years. STFT and wavelet analyses of climatic records revealed periodic variations in precipitation from April to September and in the average monthly depth of snow in February and March. The depth of snow fluctuated quasi-decadally between 1966 and 2005, with distinct peaks in 1970, 1979, 1986-1988, 1996 and 2005. The regularity was disturbed by the most recent warm and snowless decade (Fig. 2D). 

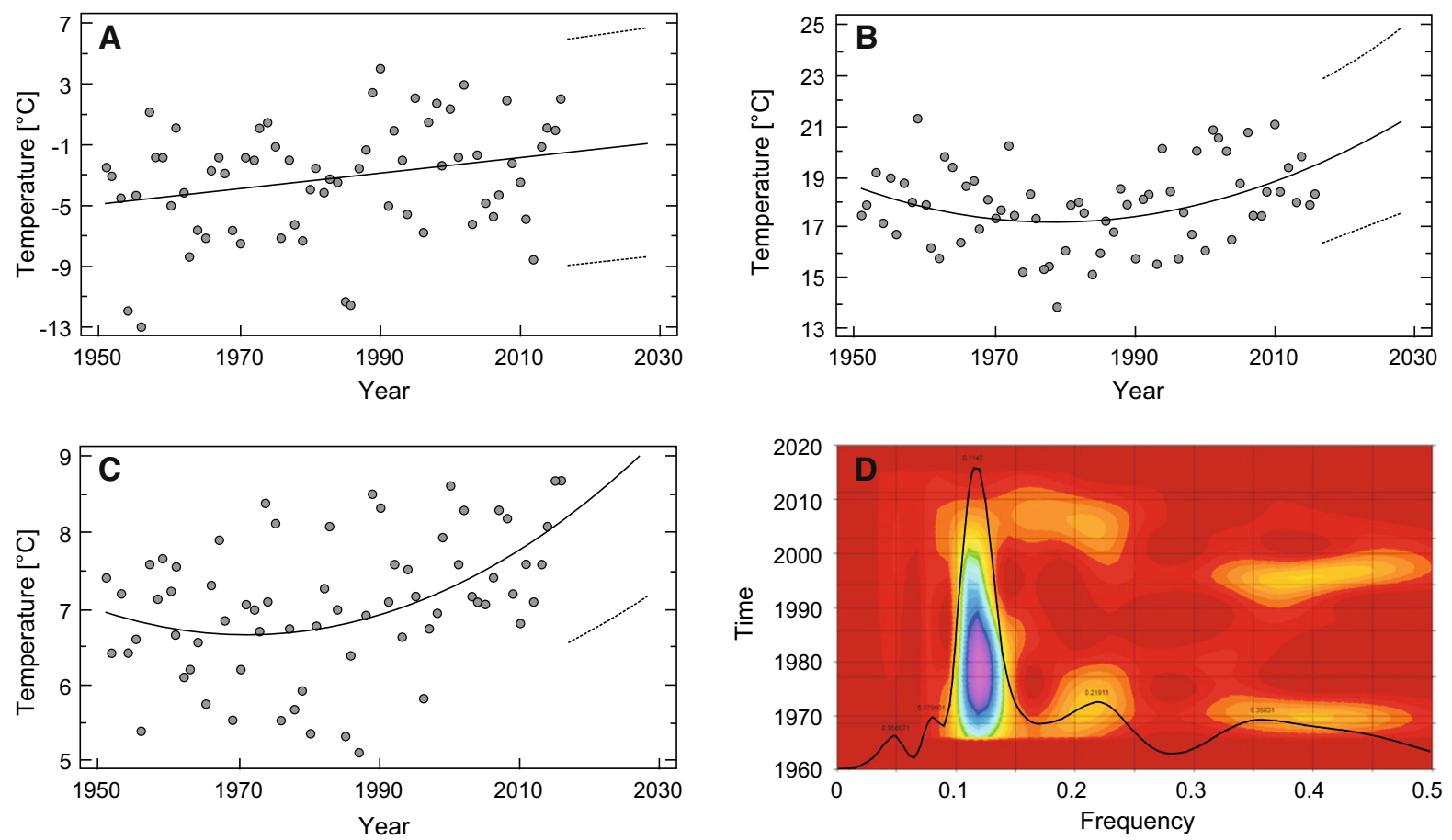

Fig. 2 Changes in the average air temperature of February (A), July (B) and temporal changes in the average annual air temperature (C) in the period 1951-2016. Dashed line is $95 \%$

The oscillatory character of precipitation from April to September was derived from three oscillations with periods of 37, 6.3, and 2.6 years. Their superimposition resulted in the precipitation pattern, which exceeded a multi-annual average by $30-70 \%$ and occurred every $\sim 13$ years in 1960, 1972, 1985, 1998 and 2010.

The mean depth of the groundwater level differed significantly across the valley (May-November; $\mathrm{n}=73$; $\mathrm{K}-\mathrm{S}$ test $\mathrm{p}<0.05)$. In the natural levee, close to the riverbed, the water level had a mean depth of $12 \mathrm{~cm}$ below ground and ranged between +40 and $84 \mathrm{~cm}$, while in the backswamp near the valley edge, the water level oscillated around the ground surface (mean $=1 \mathrm{~cm}$ below ground) and varied within the range from +45 to -50 .

The water table behavior showed the seasonal pattern rising in early spring and summer. Flooding occurred in March-April as a result of snowmelt in the basin (not shown) and, in some years, also in June and July in response to rainfall. The lowest water level was observed between August and October. In the wet years, 2007 and 2010, the water level was between 0

confidence level of forecast. Continuous wavelet time-frequency spectrum of the maximum depth of snow cover in March in the period 1966-2015 (D)

and $+20 \mathrm{~cm}$, and throughout the whole vegetation period, a considerable part of the valley was inundated (Fig. 3). There was progressive draining of the mire from 2011 to 2015, with the groundwater depth diminishing annually. The lowest water level in the Chwiszczej River valley was experienced during the extremely dry year, 2015 (Fig. 3). Close to the riverbed, the minimum recorded water table was $-84 \mathrm{~cm}$; at the valley edge, the water table dropped to $-50 \mathrm{~cm}$. Shortages in soil moisture were efficiently replenished in the wet year, 2016, by precipitation, the total of which from April to September exceeded $400 \mathrm{~mm}$.

\section{Floristic richness}

Before starting the experiment (2006), the phytocoenoses located at the riverbed (EP1) and near the edge of the valley (EP2) had a very similar floristic richness of 11-13 species. The 11 years of mowing resulted in a substantial increase in species richness in EP2, on average from 13 to 21 species (significant trend, $\mathrm{p}<0.05$ ), with a temporary drop in the years 

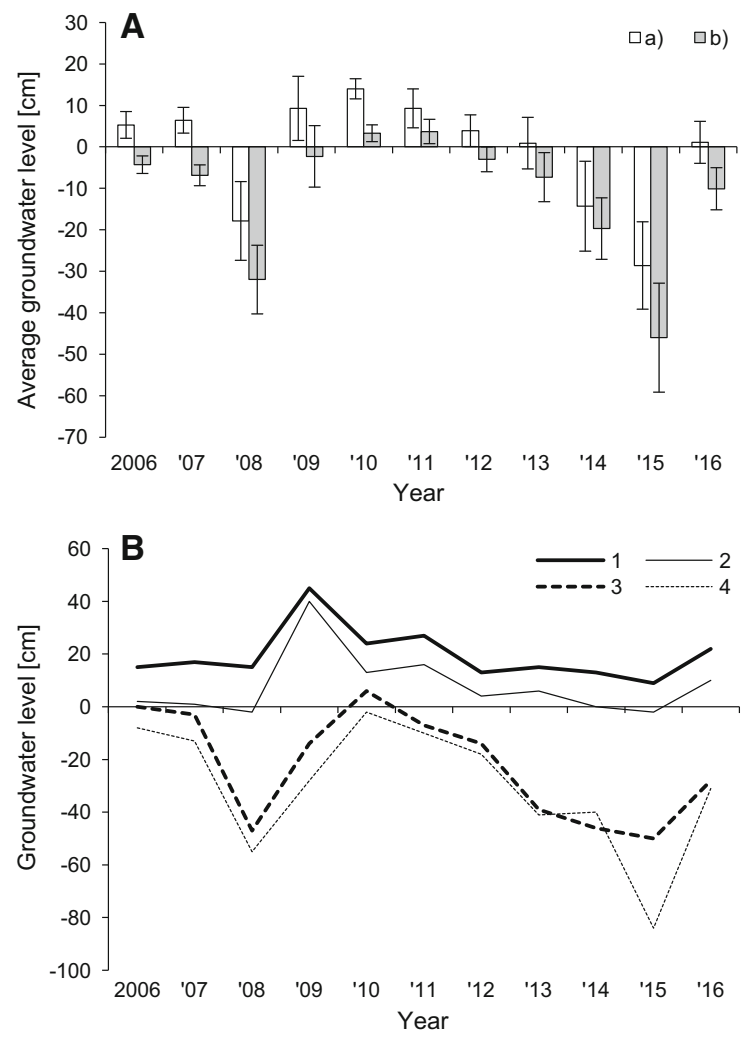

Fig. 3 Changes in groundwater level \pm SE (A) and seasonal extremes of groundwater level $(\mathbf{B})$ recorded in the near-edge zone (a) and near-stream zone (b) of the Chwiszczej valley in the period 2006-2016. Solid lines indicate the highest groundwater level recorded in the marginal (1) and central (2) part of the valley, dashed lines show the lowest groundwater level in the marginal (3) and central (4) part of the valley

2009 and 2011, when a deep and log-lasting inundation occurred (Fig. 4). The changes were less visible in the control plot (CP2), where the floristic richness grew nearly constantly from 13 to 17 species. EP1 responded to mowing to a lesser extent (11 to 17 species on average), with an extreme decline in the species number in 2012. There were no significant changes in floristic richness between experimental patch and control (Mann-Whitney U-test, p > 0.05).

\section{Species turnover}

The mowing of deeper flooded sites (EP2) resulted in the higher rate of species exchange than in the drier central part of the valley (EP1, Fig. 5). However, in EP2 the high value of T (0.52-0.61) continued only during the first 4 years of treatment and then gradually decreased to the minimum achieved in the last year of the experiment $(\mathrm{T}=0.29)$. A substantial decline was recorded in 2011. The value of the turnover index for the control plots changed in the opposite direction, rising from the minimum in the initial phase of the experiment $(T=0.23)$ to twice as high in the final stage of the study $(\mathrm{T}=0.33-0.44)$.

In the EP1 the turnover index fluctuated between $\mathrm{T}=0.45-0.51$ recorded in the first 2 years of the experiment and in 2014, and $\mathrm{T}=0.22-0.26$ appearing in 2011 and 2016. Changes in the turnover index in the control plots had a similar trend but with consistently slightly lower values.

\section{Species composition}

The reaction of vegetation to management differed depending on the location in the valley. Changes of species composition of sedge meadows patches were small in central, drier parts of the valley, most substantial-in the backswamp (Fig. 6). The ordination plot based on correspondence analysis allowed to distinguish three groups of species: (i) species of $\mathrm{C}$ and CS life strategies, mostly clonal plants associated with well-hydrated habitat, (ii) species representing mainly CSR strategy, growing on moist substrate and tolerating moderate stress and disturbances (e.g. mowing), (iii) species included in various life strategies related to disturbed habitats (drying peat substrate; Fig. 6). Wetland vegetation subjected to 11 years of annual mowing tends to change towards forms dominated by sedges with the presence of herbaceous plants characteristic of wet meadows (Calthion); these changes are much more dynamic in the marginal, wellmoistened zone of the valley. There were no clear directional changes in the species composition in unmown patches (control plots).

The sedges and cryptogams proved to be the least sensitive to management and changes in the habitat, while the least stable components of the plant patches were the forbs/megaforbs and the graminoids. The response of these plants to mowing was much more pronounced in EP1 than that in EP2 (Fig. 7). Before the experiment sedges dominated the patches adjacent to the riverbed. In the first year after mowing had begun, a coverage of herbaceous plant reached up to $48 \%$, but as the experiment progressed these species gradually reduced their abundance to just a few percent in 2015. In the eleventh year of the study, 

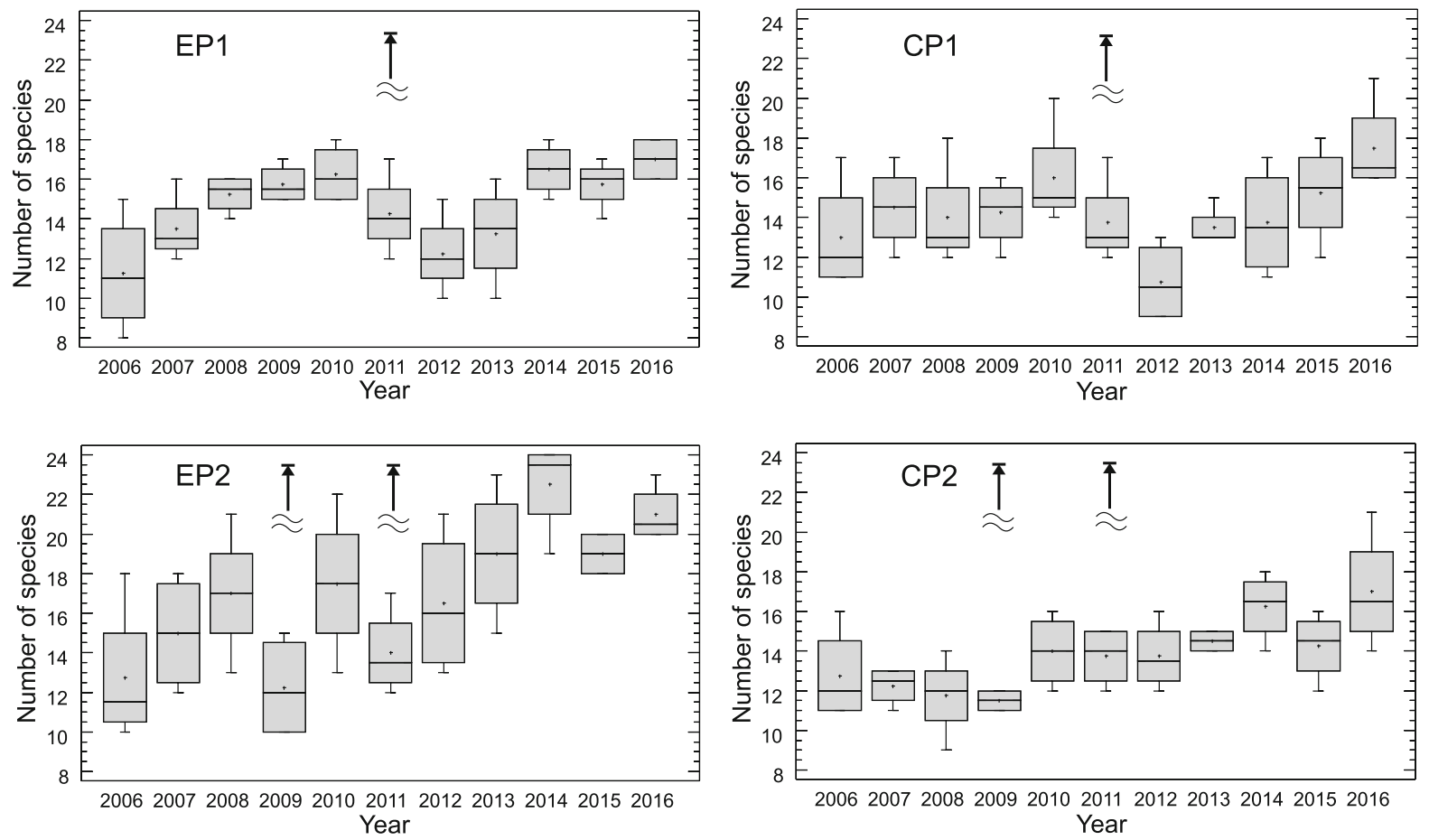

Fig. 4 Changes of floristic richness caused by annual mowing of sedge meadows in the Chwiszczej valley in the years 2006-2016. Study plots were established near the river bed

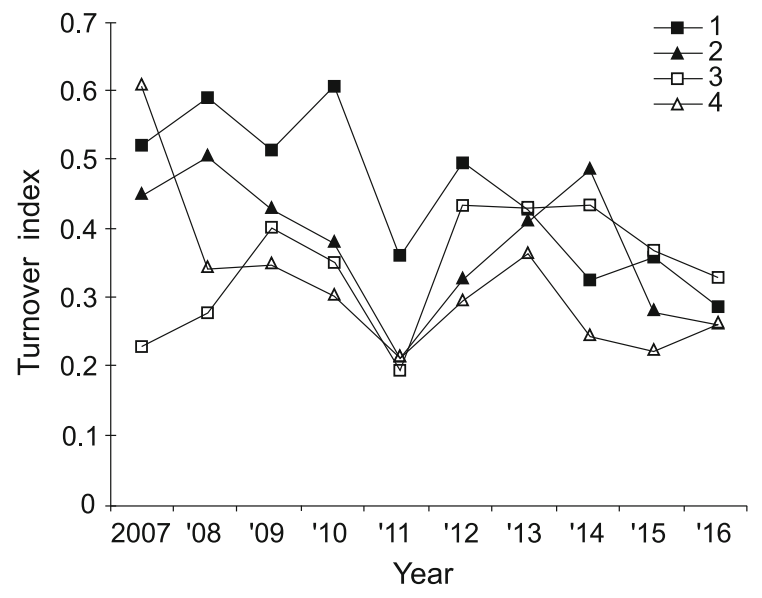

Fig. 5 Changes in species composition of sedge meadows patches in subsequent years in the period 2006-2016 measured as the turnover index (Berlin et al. 2000). The index was calculated for each season taking into account the species of vascular plants found on each $25 \mathrm{~m}^{2}$ sub-plots within experimental $(1,2)$ and control $(3,4)$ study plots established near the river bed (triangular mark) and near the edge of the valley (squared mark)

(EP1, CP1), and in the near-edge zone of the valley (EP2, CP2). $E P$ experimental plots, $C P$ control plots; the arrow shows exceptionally deep flooding

the coverage of forbs/megaforbs increased to approximately $18 \%$. Graminoids reached their maximum coverage $(\sim 27 \%)$ in 2009-2010, and then they nearly disappeared in the next two seasons (20112012). In the final phase of the experiment, the cover of grass species grew gradually to $\sim 11 \%$ in 2016 . Changes in species cover in control plots differed substantially. The coverage of herbaceous plants throughout the experiment oscillated between $20 \%$ and $40 \%$ until 2016, when the total coverage increased to over $60 \%$. In turn, the coverage of graminoids gradually declined from $\sim 20 \%$ in 2006 to zero in the last few years of the experiment.

In the experimental and control plots at the edge of the valley (EP2 and CP2), changes in the species cover of all the functional groups were in the range of several percent (Fig. 7). Only in the last phase of the experiment (2012-2016) within mown plots was a slight increase in the coverage of graminoids recorded, and in the control plots, there was a slight increase in the coverage of forbs. The response to annual mowing and the changing water conditions was particularly high in megaforbs. The species of this group were 


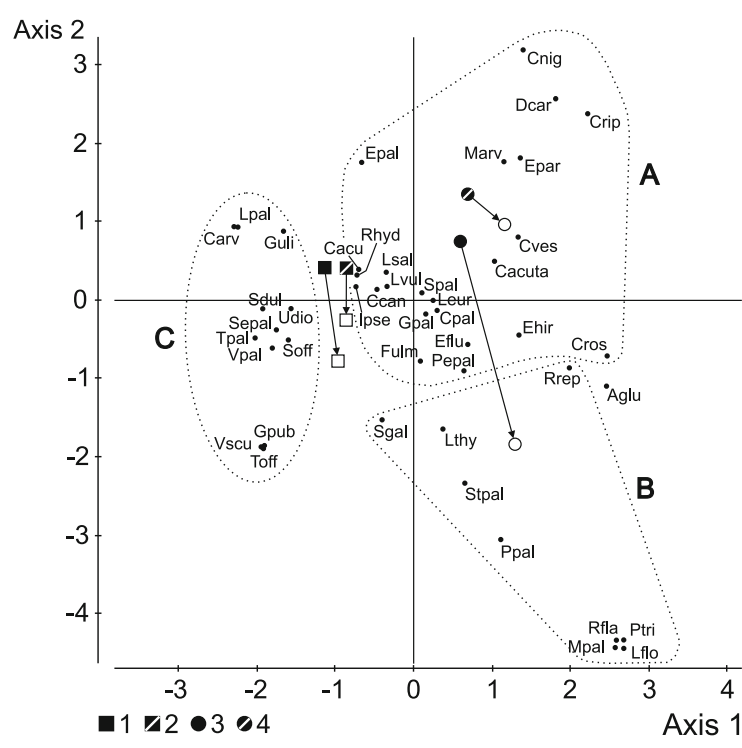

Fig. $6 \mathrm{CA}$ ordination biplot of relevés showing the overall changes in species composition of mown (1 EP1, 3 EP2) and unmown (2 CP1, 4 CP2) research plots established within sedge meadows communities. Filled symbols indicate the position of initial relevés (2006), blank symbols - the position of final ones (2016); location of research plots: EP1, CP1-near-stream (drier) zone, EP2, CP2-marginal (wetter, subjected to deeper and longer flooding) zone of the river valley. Variance explained by axis 1 (soil moisture gradient)-34.6\%; variance explained by axis 2 (management gradient)-23.8\%. A competitive species, representing mostly $\mathrm{C}$ and $\mathrm{CS}$ strategies; $B$ species tolerating moderate disturbances and stress, representing mostly CSR strategy; $C$ species representing various life strategies, associated with disturbed habitats

more abundant near the riverbed than those in the wet patches adjacent to the edge of the valley.

Forest species appeared sparsely within the studied wetland. However, the presence of black alder seedlings grew distinctly in the mown plots situated close to the valley edge (EP2). Their abundance peaked in the fifth and sixth year of the experiment when the density of juvenile individuals of Alnus was 33 and 23 per $100 \mathrm{~m}^{2}$, respectively (Fig. 8). No alder seedlings were found on unmown plots during experiment.

\section{Discussion}

Hydrology, especially water dynamics, is a crucial causal factor that shapes the composition and func- tions of wetland ecosystems (Keddy 2010). That is evident in fluviogenic wetlands, which every year undergo floods that vary within and between years, and where the vegetation is controlled by the fluctuating water conditions. A characteristic feature of vegetation is cyclic changes in species composition and structure induced by the variation of the water table, depth and duration of flooding, and drought events (Niering 1989).

In the Chwiszczej River valley, the hydrologic conditions are sustainable for tree-less communities in its highly paludified lower stretch, close to its junction with the Leśna River. Hydrology supportive of the persistence "open" mire is especially distinctive of the wet depressions at the valley margins. In backswamps inundation is up to $40-50 \mathrm{~cm}$ deep and lasts for some years to July/August. The central part of the valley close to the riverbed is slightly elevated over the rest of a floodplain due to a formation of natural levees and therefore is drier. Close to the river the flooding is shallower, and pass off already in March-April. During the summer droughts the water table drops down to $30-50 \mathrm{~cm}$ below ground level with extremes reaching to $80 \mathrm{~cm}$ b.g.l.

Carex communities dominated the wetland, through the whole period of organic accumulation. However, several hundred years ago, forests and woodlands with the domination of Alnus glutinosa encroached on the valley; the occurrence of which was confirmed by the presence of a thin Carex-Alnus peat layer at a depth of ca. $0.5 \mathrm{~m}$ (Kołos 2012). Ca. 200-250 years ago, the Chwiszczej valley, like many lowland valley wetlands in central Europe (Kaplan et al. 2009), was deforested and converted into extensive meadows. Forest clearance, which also occurred at the catchment scale, contributed to farreaching changes in mire formation, i.e., the accumulation of rush and sedge peat that resulted from increased water availability, due to decreased evapotranspiration.

Between the seventeenth century and the second half of the twentieth century, low-intensity agriculture contributed to the development of herbaceous fen oscillating around a quasi-stable equilibrium state controlled by climate, farming practices and hydrological disturbances, such as the regulation of the riverbed and reclamation work performed locally in the upper part of the valley. 

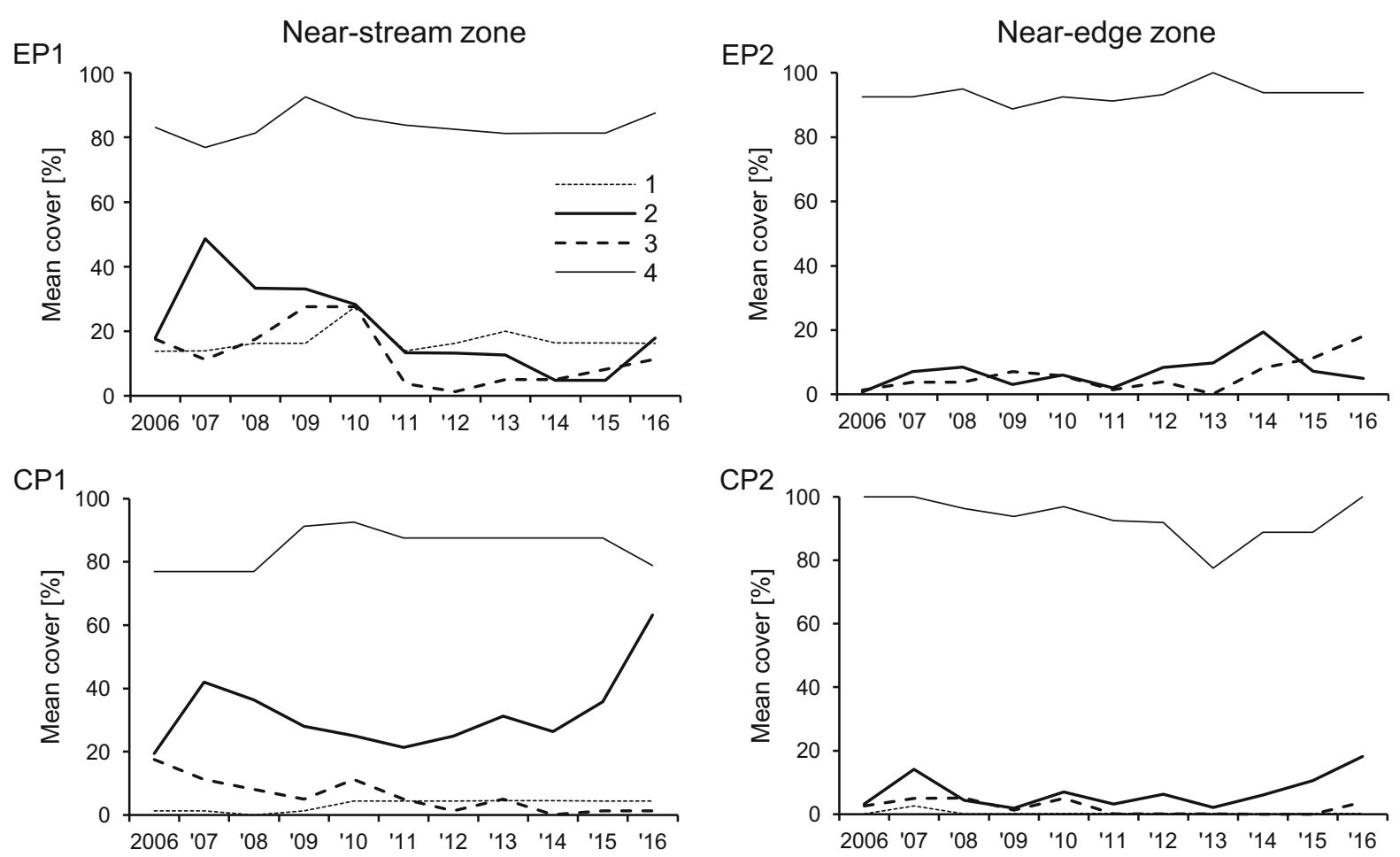

Fig. 7 Effect of 10-year (2006-2016) mowing of sedge meadows patches on plant species cover. Four functional groups of plants were distinguished: 1-cryptogams, 2forbs/megaforbs, 3-graminoids, 4-sedges; EP experimental

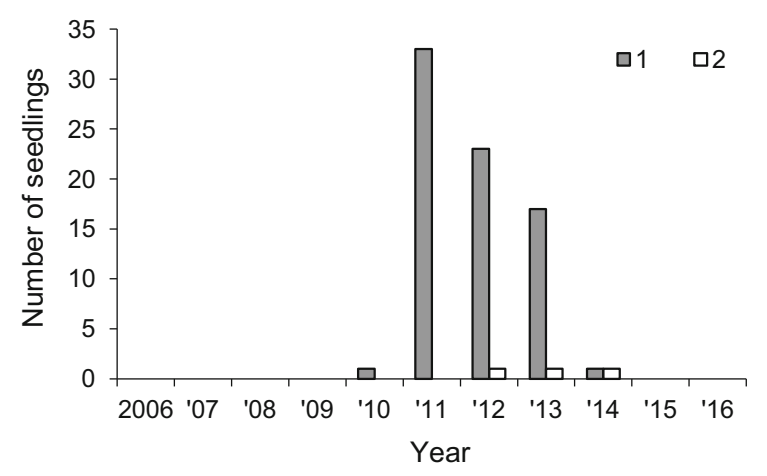

plots, $C P$ control plots. For every group of plants average percentage cover of species found on four sub-plots $25 \mathrm{~m}^{2}$ included in the experimental and control plots was calculated

plants. Some of these meadows with specific combinations of species are in danger of disappearing and are protected by law as valuable remnants of traditional management (van Diggelen et al. 2006; Grzelak et al. 2011).

Influence of mowing on the floristic structure of sedge meadows: lessons learned

The reaction of vegetation to mowing differed depending on the location in the floodplain and hydroperiod. In the backswamp during the first 5

Fig. 8 Effect of long-term mowing (2006-2016) on the occurrence of black alder seedlings within sedge meadows in the Chwiszczej valley. Alnus glutinosa seedlings were found only on experimental (1) and control (2) plots established in the marginal part of the valley. Counting was carried out on plots $100 \mathrm{~m}^{2}$

After centuries of mowing and the removal of biomass, the equilibrium vegetation took the form of Carex meadows, which differed from "typical" ("natural") rushes by an abundance of herbaceous years of the experiment, the floristic composition of the mown plots changed to a rather limited extent. The most striking result of the treatment was a retreat of grasses, which was also recorded in a trial by Menichino et al. (2016) conducted within the degraded fen communities. The slight increase in the grass species cover in the experimental plots, which occurred during the last 3 years of the study was a phenomenon related to the distinct drop in 
groundwater table and soil wetness caused by relatively low precipitation in the years 2013-2016. Mowing in that part of the valley was successful at fostering an abundance of short-growing forbs, as in other studies (Gerard et al. 2008; Neuenkamp et al. 2013). In the second phase of the experiment, we noticed a slight increase in the coverage of herbaceous plants, which, however, finally began to recede. This retreat was related to megaforbs, which were found to not tolerate a summer mowing (Valkó et al. 2012; Temu et al. 2015).

In the drier central part of the valley changes in the floristic composition under the mowing treatment had a similar but much more dynamic nature. We noticed a considerable increase in the coverage of some species after the implementation of mowing and, subsequently, their substantial decrease in the second phase of the experiment. This was especially noticeable for herbs, whose mowing resulted in a drop in their cover from $48 \%$ in 2007 to only $5-18 \%$, while the opposite results were noticed in control plots where some increase in the share of these species occurred.

The mowing of sedge meadows in the annually flooded river valley increased their floristic richness, but the variability within the patches was relatively small. The number of species after tenfold mowing in the central drier part of the wetland increased by only 4-6 taxa (17 vs. 11-13 species), and the patches did not show substantial differences from unmown ones. In the marginal backswamp, treatment changed the floristic richness substantially ( 21 vs. 13 species). Similarly, the changes in the number of species representing the CSR strategy (Grime 2001) on the experimental plots located in the central zone of the valley were small (from 1 to 4 species $/ 100 \mathrm{~m}^{2}$ ), whereas in the near-edge zone the increase was substantial (1-7 species).

Mowing along with trampling by a haymaker lays open the ground surface, which is over-shaded and covered by dead biomass, contributing to the formation of microhabitats in the form of numerous new gaps. These gaps have been found to be a significant predictor of species richness (Poschlod and Biewer 2005; Hellström et al. 2009). However, our results suggest that supportive effect of management on floristic composition is more visible in (sometimes restricted to) wetter parts of wetland, with a specific vegetation structure shaped by a prolonged surface flooding.
A long-lasting inundation, which is characteristic for the backswamps, supports and maintains the presence of numerous hummocks and hollows. Carex acutiformis and C. acuta form tussocks up to $40 \mathrm{~cm}$ high; even creeping sedges take this form of growth. Because the valley in the spring is flooded for many weeks and, therefore, hollows are unavailable for plant propagules (from seed bank or seed dispersal from the parent plants), the colonization after gaps are exposed often starts from the hummocks and tussocks formed by Carex spp. These "discrete micro-islands" are usually inhabited by resident species that depend on tussocks for quasi-stable habitats elevated above the flooded soil surface (see Peach and Zedler 2006). In contrast, in the wetland characterized by a higher water dynamic, where inundation typically ends already at the turn of April and May, mowing induced a vigorous vegetative spread of the dominant Carex species, which created a dense and uniform cover, leaving few free spaces for other species.

The most active species exchange occurred in the initial stage of the experiment. However, in the subsequent years, this process declined sharply, what was probably associated with the excessive frequency of treatments. A similar change in managed meadows indicated also experimental studies by other authors (e.g., Huhta and Rautio 1998).

Experimental research in the Chwiszczej valley confirmed our earlier statements (Kołos and Banaszuk 2013) that long-lasting annual mowing of sedge meadows in the middle of the growing season did not result in their transformation into polydominant wet meadows. However, the effect of treatment differed depending on hydroperiod. Independent of the local variability, the mowing of sedge meadows in annually flooded river valley resulted in dominance by adventitious sedges with quite a low share of herbs (e.g. Lythrum salicaria, Galium palustre, Lycopus europaeus, Scutellaria galericulata, Symphytum officinale), grasses (Calamagrostis canescens, Poa palustris, Poa trivialis), and ferns (Thelypteris palustris, Dryopteris carthusiana). The phytocenoses reached an alternative stable state that fluctuated around some "average pattern" determined by general habitat conditions. We noticed that the phytocenoses were sensitive to groundwater dynamics, especially longlasting flood and water deficits; under such conditions, the dominant species, such as Carex acutiformis and C. acuta could be displaced by $C$. riparia (in the 
marginal zone of the valley) or by Calamagrostis canescens and Phalaris arundinacea (in the central part of the valley; Fig. 9). The described pattern differed from that, which was found for the sporadically flooded sedge meadows (Kołos and Banaszuk 2013). In the absence of inundation, the transformation of annually mowed vegetation occurred in several stages, with successive dominance of various species groups, mainly low and tall forbs (Cirsium palustre, Lysimachia vulgaris, Ranunculus repens), ferns (Thelypteris palustris) and grasses (Calamagrostis canescens, Phragmites australis). Some plant species were able to achieve the status of dominants or codominants because mowing resulted in a substantial weakening of the competitiveness of Carex acutiformis (after several years of mowing the cover of this species decreased to about 40-50\%). The weakness of the principal competitor favored the formation of small gaps within vegetation cover, which were occupied by numerous herbs. After 15 years of mowing, regardless of the environmental gradient, almost twice as many species were recorded in the research plots than before the experiment started.

Mowing versus Alnus glutinosa seedling propagation

The distribution of woody species within sedge meadows is limited primarily by competition from clonal plants. However, mowing weakens the competitiveness of these species and promotes the formation of gaps within plant cover, which allows seeds of other plants to germinate. The phenomenon of abundant appearance of juvenile individuals of Alnus in patches subjected to mowing in the vicinity of the forest was previously described by Kołos (1991). It is likely related to the method of black alder seed dispersion. Light-winged seeds fall to the snow cover near the parent plants, and then these seeds are blown by the wind or run down with the melt-water toward the open, lower-lying parts of the valley. The year of the abundance of seedlings (2011) was preceded by a very snowy winter, with the maximum snow depth of $65 \mathrm{~cm}$. In the subsequent seasons, with a shallow, short-lasting snow cover, the efficiency of the dispersion of alder seeds in the Chwiszczej valley was considerably lower. Snowy winters that occur in NE Poland approximately every 9 years are most likely to initiate the enhanced propagation of Alnus.

Effect of hydrological conditions and climate on sedge meadow vegetation

Surface flooding was found to be a driving force modifying the impact of mowing on vegetation and individual plant species (Kennedy et al. 2003; Leyer 2005; Toogood and Joyce 2009; Zelnik and Čarni 2013). In our experiment, annual mowing combined with the removal of biomass initially supported the growth of low herbs. But in the 4- and 6-years of management, due to natural hydrological pulses (prolonged floods sustained by heavy rainfall) many

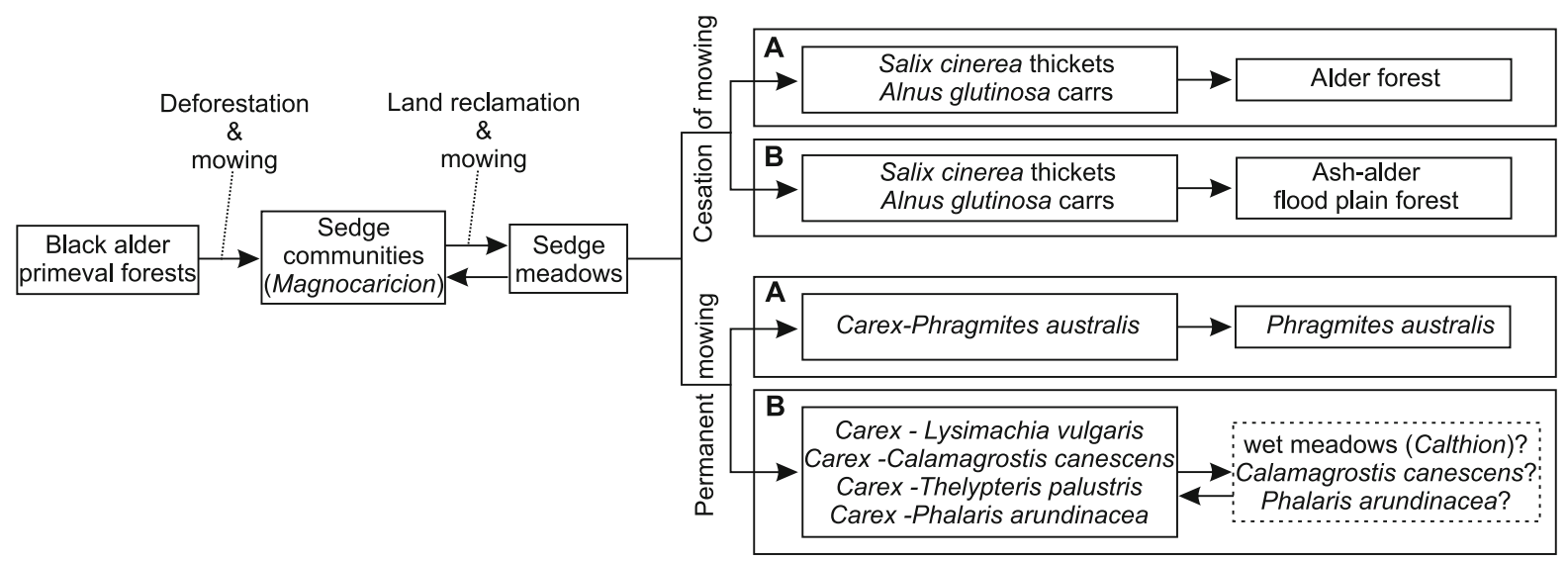

Fig. 9 Transformation of vegetation of flooded small lowland river valley caused by management and diverse hydrological conditions ( $A$ long lasting flood, permanent moisture habitat; $B$ short lasting flood, temporary dry habitat). The pattern of changes in vegetation was based on long-term research carried out in the Narewka river valley in the Białowieża National Park (Kołos and Banaszuk 2013), and in the Chwiszczej river valley 
of species that could not resist short-term environmental fluctuations periodically disappeared from both the experimental and control plots. Excessive increases in habitat wetness created a specific floristic reset of this natural system, bringing it back to the form dominated by few wetland species.

Under the transitional climate of central Europe, there is a typical hydrological swing between drier and wetter years. The "extremely" wet years with precipitation greatly exceeding the annual mean seem to occur approximately every 12 years. Exceptionally snowy winters occur with a quasi-decadal regularity, resulting in thicker snowfall and, after melting, longer inundation of the wetlands. Rainy summers and snowy winters peak with a phase shift, giving a periodic variation in extreme wet years occurring at 6- to 8-year intervals.

Although the existence of periodic quasi-decadal variations in climate parameters is somewhat controversial, there is a growing array of evidence for their presence. Keeling and Whorf (1997) described $\sim 6$ and 9-year oscillations in global air temperatures and proposed a tidal mechanism to explain it. Cycles of $6.2,18.6$, and 55.8 years have been identified in timeseries for the Barents Sea by Yndestad (1999, 2003). Since periodicities in temperature are likely to cause cyclic changes in other aspects of weather, i.e., precipitation, it is conceivable that the patterns in rainfall evident in NE Poland were caused by the same driving forces.

The impact of climate factors on sedge meadow ecosystems is difficult to determine due to the short period of our study. In the first few years of mowing, the intensity of the transformation of flora was greater in the managed patches (e.g., the decrease in the rate of species exchange and coverage of some groups of plant species in 2010-2011). It seemed, therefore, that patches already subjected to mowing were more sensitive to changes in hydrology and that the observed transformations were the result of the cumulative effect of both disturbances. However, after 9-10 years of cutting in the near-riverbed zone of the valley, the floristic structure of the mown patches appeared to be more stable than that of the unmown ones, e.g., regarding changes in forb cover. These results likely suggested that wetland vegetation was more effectively shaped by climate and hydrological conditions than by management, which was also reported by Sletvold et al. (2013), Laitinen et al. (2008) and Xu et al. (2007).

Conclusions and implications of the results

for conservation of valley wetlands

Management of vegetation within fluviogenous mires with well preserved (or restored) hydrological patterns did not result in substantial floristic changes in Carex phytocenoses. According to our findings, mowing altered the structure of sedge meadows to a relatively small extent, and the effect of cutting was limited to the maintenance of its internal mosaicity and to the hindrance of the expansion of trees and shrubs. Mowing increased the floristic diversity mainly within sedge meadows placed in the more waterlogged parts of the river valley. However, every change in flora diversity suggesting the transformation of vegetation toward multispecies meadows that occurred during the relatively dry years was reversed after long-lasting and profound inundation during the wet years. This "hydrological resetting impulse" brought these ecosystems back to the state characterized by the dominance of sedges with a low admixture of herbs and grasses.

A scythe or sickle bar mower is the preferred cutting device compared to mowing machines, which was found to exert an adverse effect on flora, fauna, and microtopography of managed wetlands (Humbert et al. 2009; Banaszuk et al. 2016), primarily when performed on well-watered peat soils. Only a few authors suggest that there are no apparent differences in vegetation composition of grasslands in the effect of different mowing techniques (Tälle et al. 2014). Accordingly, mowing with hand scythe due to its low invasiveness should be recommended for use in protected areas. However, as this technique is loweffective and very labor and time-consuming, it cannot rather be applied on a larger scale.

It is very likely that annual mowing of the sedgedominated communities is redundant. It is sufficient to repeat this procedure every $4-5$ years in the beginning of August when most of the plant species end their flowering and when the seeds have a chance to germinate in exposed areas. This mowing regime is also beneficial for the protection of birds (Antoniazza et al. 2017).

The treatment should not be discarded. The abandonment of mowing (e.g., due to financial depletion) 
in the season with profuse seed dispersion of Alnus (or in the following 2 years) can significantly accelerate the process of secondary succession and conduct to the formation of alder carrs. In our opinion, planning for short-term protection measurements within non-forest plant communities in river valleys is not a good solution because these protections can lead to opposite effects of those intended.

Acknowledgements We gratefully acknowledge two anonymous reviewers for their thoughtful comments and suggestions which helped to improve our manuscript. This research was supported by Białystok University of Technology (Grant S/WBiIS/1/2017).

Open Access This article is distributed under the terms of the Creative Commons Attribution 4.0 International License (http:// creativecommons.org/licenses/by/4.0/), which permits unrestricted use, distribution, and reproduction in any medium, provided you give appropriate credit to the original author(s) and the source, provide a link to the Creative Commons license, and indicate if changes were made.

\section{References}

Antoniazza M, Clerc C, Le Nédic C, Sattler T, Lavanchy G (2017) Long-term effects of rotational wetland mowing on breeding birds: evidence from a 30-year experiment. Biodivers Conserv. https://doi.org/10.1007/s10531-017-14621

Banaszuk P, Kamocki AK, Zarzecki R (2016) Mowing with invasive machinery can affect chemistry and trophic state of rheophilous mire. Ecol Eng 86:31-38

Barkman JJ (1988) New system of plant growth forms and phenological plant types. In: Werger MJA, Van der Aart PJM, During HJ, Verhoeven JTA (eds) Plant form and vegetation structure. SPD Academic Publishing, The Hague, pp 9-44

Berglund BE, Gaillard MJ, Bjørkman L, Persson T (2008) Longterm changes in floristic diversity in southern Sweden: palynological richness, vegetation dynamics and land-use. Veg Hist Archaeobot 17:573-583

Berlin GAI, Linusson A-C, Olsson EGA (2000) Vegetation changes in semi-natural meadows with unchanged management in southern Sweden, 1965-1990. Acta Oecol 21:125-138

Gerard M, El Kahloun M, Rymen J, Beauchard O, Meire P (2008) Importance of mowing and flood frequency in promoting species richness in restored floodplains. J Appl Ecol 45:1780-1789

Grime JP (2001) Plant strategies, vegetation processes, and ecosystem properties. Wiley, Chichester

Grygoruk M, Batelaan O, Mirosław-Świątek D, Szatyłowicz J, Okruszko T (2014) Evapotranspiration of bush encroachments on a temperate mire meadow-a nonlinear function of landscape composition and groundwater flow. Ecol Eng 73:598-609

Grzelak M, Waliszewska B, Sieradzka A, Speak-Dźwigała A (2011) Ekologiczne zbiorowiska łąkowe $\mathrm{z}$ udziałem gatunków z rodziny turzyc (Carex). J Res Appl Agri Eng 56:122-126

Hellström K, Huhta A-P, Rautio P, Tuomi J (2009) Seed introduction and gap creation facilitate restoration of meadow species richness. J Nat Conserv 17:236-244

Horak J, Safarova L (2015) Effect of reintroduced manual mowing on biodiversity in abandoned fen meadows. Biologia 70:113-120

Huhta AP, Rautio P (1998) Evaluation the impacts of mowing: a case study comparing managed and abandoned meadow patches. Ann Bot Fenn 35:85-99

Humbert J-Y, Ghazoul J, Walter T (2009) Meadow harvesting techniques and their impacts on field fauna. Agr Ecosyst Environ 130:1-8

Joyce CB (2014) Ecological consequences and restoration potential of abandoned wet grasslands. Ecol Eng 66:91-102

Kaplan JO, Krumhardt KM, Zimmermann N (2009) The prehistoric and preindustrial deforestation of Europe. Quaternary Sci Rev 28:3016-3034

Keddy PA (2010) Wetland ecology: principles and conservation. Cambridge University Press, Cambridge

Keeling CD, Whorf TP (1997) Possible forcing of global temperature by the oceanic tides. Proc Natl Acad Sci USA 94:8321-8328

Kennedy MP, Milne JM, Murphy KJ (2003) Experimental growth responses to groundwater level variation and competition in five British wetland plant species. Wetl Ecol Manag 11:383-396

Kołos A (1991) Oddziaływanie sąsiedztwa lasu na przebieg sukcesji na porzuconych łąkach w dolinie Narewki. Phytocoenosis 3:119-126

Kołos A (2012) Effect of mowing on the structure of sedge communities in the Chwiszczej river valley (Białowieża Forest). Quaestiones Geographicae 31:33-39

Kołos A, Banaszuk P (2013) Mowing as a tool for wet meadows restoration: effect of long-term management on species richness and composition of sedge-dominated wetland. Ecol Eng 55:23-28

Laitinen J, Rehell S, Oksanen J (2008) Community and species responses to water level fluctuations with reference to soil layers in different habitats of mid-boreal mire complexes. Plant Ecol 194:17-36

Leyer I (2005) Predicting plant species' responses to river regulation: the role of water level fluctuations. J Appl Ecol 42:239-250

Marcinkowski P, Grygoruk M (2017) Long-term downstream effects of a dam on a lowland river flow regime: case study of the Upper Narew. Water 9:783. https://doi.org/10.3390/ w9100783

Menichino NM, Fenner M, Pullin AS, Jones PS, Guest J, Jones L (2016) Contrasting response to mowing in two abandoned rich fen plant communities. Ecol Eng 86:210-222

Middleton BA, Holsten B, van Diggelen R (2006) Biodiversity management of fens and fen meadows by grazing, cutting and burning. Appl Veg Sci 9:307-316 
Milberg P, Tälle M, Fogelfors H, Westerberg L (2017) The biodiversity cost of reducing management intensity in species-rich grasslands: mowing annually vs. every third year. Basic Appl Ecol 22:61-74

Natlandsmyr B, Hjelle KL (2016) Long-term vegetation dynamics and land-use history: providing a baseline for conservation strategies in protected Alnus glutinosa swamp woodlands. Forest Ecol Manag 372:8-92

Neuenkamp L, Metsoja JA, Zobel M, Hölzel N (2013) Impact of management on biodiversity-biomass relations in Estonian flooded meadows. Plant Ecol 214:845-856

Niczyporuk A, Wiater J (2006) The influence of basin use of Chwiszcza and Perebel River on seasonal quality of discharge water. Pol J Environ Stud 15:397-400

Niering WA (1989) Wetland vegetation development. In: Majumdar SK, Brooks RP, Brenner FJ, Tiner JRW (eds) Wetlands ecology and conservation: emphasis in Pennsylvania. Pennsylvania Academy of Science, Easton, pp 103-113

Pałczyński A (1984) Natural differentiation of plant communities in relation to hydrological conditions of the Biebrza Valley. Pol Ecol Stud 10:347-385

Peach M, Zedler JB (2006) How tussocks structure sedge meadow vegetation. Wetlands 26:322-335

Podani J (1993) SYN-TAX 5.0: computer programs for multivariate data analysis in ecology and systematics. Abstracta Botanica 17:289-302

Poschlod P, Biewer H (2005) Diaspore and gap availability are limiting species richness in wet meadows. Folia Geobot 40:13-44

Seer FK, Schrautzer J (2014) Status, future prospects, and management recommendations for alkaline fens in an agricultural landscape: a comprehensive survey. J Nat Conserv 22:358-368

Sletvold N, Dahlgren JP, Øien D-I, Moen A, Ehrlén J (2013) Climate warming alters effects of management on population viability of threatened species: results from a 30-year experimental study on a rare orchid. Glob Change Biol 19:2729-2738

Sorrell BK, Partridge TR, Clarkson BR, Jackson RJ, Chague'Goff C, Payne P, Gerbeaux C, Grainger NPJ (2007) Soil and vegetation responses to hydrological manipulation in a partially drained polje fen in New Zealand. Wetl Ecol Manag 15:361-383

Tälle M, Bergman K-O, Paltto H, Pihlgren A, Svensson R, Westerberg L, Wissman J, Milberg P (2014) Mowing for biodiversity: grass trimmer and knife mower perform equally well. Biodivers Conserv 23:3073-3089

Tälle M, Fogelfors H, Westerberg L, Milberg P (2015) The conservation benefit of mowing vs grazing for management of species-rich grasslands: a multi-site, multi-year field experiment. Nord J Bot 33:761-768

Temu VW, Baldwin BS, Reddy KR, Riffell SK (2015) Harvesting effects on species composition and distribution of cover attributes in mixed native warm-season grass stands. Environments 2:167-185

Thuiller W, Lavorel S, Araujo MB, Sykes MT, Prentice IC (2005) Climate change threats to plant diversity in Europe. Proc Natl Acad Sci USA 102:8245-8250

Toogood SE, Joyce CB (2009) Effects of raised water levels on wet grassland plant communities. Appl Veg Sci 12:283-294

Tyszka J (2008) Hydrologiczne funkcje lasu w małych nizinnych zlewniach rzecznych. Prace Instytutu Badawczego Leśnictwa, Sękocin Stary

Valkó O, Török P, Matus G, Tóthmérész B (2012) Is regular mowing the most appropriate and cost-effective management maintaining diversity and biomass of target forbs in mountain hay meadows? Flora 207:303-309

van der Maarel E (1979) Transformation of cover-abundance values in phytosociology and its effects on community similarity. Ecology 39:97-114

van Diggelen R, Middleton B, Bakker J, Grootjans A, Wassen M (2006) Fens and floodplains of the temperate zone: present status, threats, conservation and restoration. Appl Veg Sci 9:157-162

Xu H, Ye M, Li J (2007) Changes in groundwater levels and the response of natural vegetation to transfer of water to the lower reaches of the Tarim River. J Environ Sci 19:1199-1207

Yndestad H (1999) Earth nutation influence on the temperature regime of the Barents Sea. ICES J Mar Sci 56:381-387

Yndestad H (2003) A Lunar nodal spectrum in Arctic time series. 2003 ICES Annual Science Conference. Tallinn. ICES CM 2003/T

Zelnik I, Čarni A (2013) Plant species diversity and composition of wet grasslands in relation to environmental factors. Biodivers Conserv 22:2179-2192

Żmihorski M, Pärt T, Gustafson T, Berg Å (2015) Effects of water level and grassland management on alpha and beta diversity of birds in restored wetlands. J Appl Ecol 53:587-595 